\title{
FOREST LAND-COVER CHANGES 2012-2018 IN HUNTING GROUNDS IN VOJVODINA
}

\author{
Vladimir Marković ${ }^{1}$, Milosava Matejević ${ }^{2}$, Milutin Kovačević3, Zoran Ristić, \\ Lukrecija Đeri ${ }^{5}$, Igor Ponjiger 6 \\ *Corresponding authorE-mail: milosava@dgt.uns.ac.rs
}

A R T I C L E I N F O
Original Article
Received: 18 September 2020
Accepted: 18 November 2020
doi:10.5937/ekoPolj2004059M
UDC 332:334.4:630]:639.1.052
(497.113)"2012/2018

Keywords:

forestation, CLC, GIS, hunting ground, Vojvodina, Serbia

JEL: Q51, Q23, R14

\begin{abstract}
A B S T R A C T
Deforestation could influence land cover ecological significance in hunting grounds on a big scale. This research examines changes of forest and shrub patches in the Vojvodina region by a set of landscape metrics. The study area includes 154 hunting grounds from which hunting organizations are managing with 134 hunting grounds, PC "Vojvodinasume" with 17, Serbian Armed Forces with two, and National Park "Fruska gora" with one hunting ground. The results show that in the National Park and Serbian Armed Forces hunting grounds the broad-leaved forest areas occurred on the surfaces that were under the transitional woodland-shrub and vice versa. A similar situation is in the hunting grounds managed by PC "Vojvodinasume" where there is not only the most intensive logging of broad-leaved and coniferous forests but also the most intensive afforestation of mixed forests and transitional woodland-shrub. On the other hand, in the hunting grounds managed by hunting organizations, there is the highest area growth under the broad-leaved forest.
\end{abstract}

(C) 2020 EA. All rights reserved.

1 Vladimir Marković, associate professor, Department of Geography, Tourism and Hotel Management, Faculty of Sciences, University of Novi Sad, Trg Dositeja Obradovića 3, 21000 Novi Sad, Serbia, Phone: +381214852845, E-mail: vladimir.marković@dgt.uns.ac.rs, ORCID ID (https://orcid.org/0000-0002-6545-5263)

2 Milosava Matejević, assistant professor, Department of Geography, Tourism and Hotel Management, Faculty of Sciences, University of Novi Sad, Trg Dositeja Obradovića 3, 21000 Novi Sad, Serbia, Phone: +381214852845, E-mail: milosava@dgt.uns.ac.rs, ORCID ID ( https://orcid.org/0000-0001-5345-774X)

3 Milutin Kovačević, teaching assistant, Department of Geography, Tourism and Hotel Management, Faculty of Sciences, University of Novi Sad, Trg Dositeja Obradovića 3, 21000 Novi Sad, Serbia, Phone: +381214852845, E-mail: milutin.kovacevic@dgt.uns.ac.rs, ORCID ID (https://orcid. org/0000-0002-7260-6066)

4 Zoran Ristić, full professor, Department of Geography, Tourism and Hotel Management, Faculty of Sciences, University of Novi Sad, Trg Dositeja Obradovića 3, 21000 Novi Sad, Serbia, Phone: +381214852845, E-mail: zoran.ristic@dgt.uns.ac.rs, ORCID ID (https://orcid.org/0000-0001-7273-1177)

5 Lukrecija Đeri, full professor, Department of Geography, Tourism and Hotel Management, Faculty of Sciences, University of Novi Sad, Trg Dositeja Obradovića 3, 21000 Novi Sad, Serbia, Phone: +381214852845, E-mail: lukrecija.djeri@dgt.uns.ac.rs, ORCID ID (https://orcid.org/0000-0002-4628-7647)

6 Igor Ponjiger, research associate, Department of Geography, Tourism and Hotel Management, Faculty of Sciences, University of Novi Sad, Trg Dositeja Obradovića 3, 21000 Novi Sad, Serbia, Phone: +381214852845, E-mail: igor.ponjiger@dgt.uns.ac.rs, ORCID ID (https://orcid.org/0000-0001-9426-5250) 


\section{Introduction}

Permanent logging was typical in the industrialized world until a few decades ago. Vast areas under forest worldwide were clear cut for industrial expansion, economic development, or agriculture. Today deforestation is occurring on a large scale not only in tropical countries in Africa, Asia, and Latin America (Steininger et al., 2001; Chowdhury, 2006) but also in taiga regions, like in Russia or Canada (Tracy, 1994). One of the main problems in forest policies stems from the fact that there are not enough adequate and proper forestation monitoring (Dale, 2008; Monteiro, Souza, 2012). What's more, illegal logging and corrupt activities lead to forest decline worldwide (Brack, 2003; Markus-Johansson et al., 2010). The legislative framework for sustainable development, in agriculture and generally defines the rights to a healthy environment, and the duty to protect and improve the environment in accordance with the law (Tomaš Simin et al., 2019). What's more, the effect of the greenhouse is related to the increase of $\mathrm{CO} 2$ in the atmosphere, and one of the biggest polluters is changes in the use of land and forest - logging (Počuča et al., 2017).

Although the Environmental Performance Index (EPI) of the forest category in Serbia is above the average score of the top 16 European countries (Radivojvević et al., 2019) there are still big challenges related to forestry, especially in Vojvodina province. In Serbia, about $30 \%$ of the total area is under forest (Jovanović, Milanović, 2015; Vukajlović et al., 2017) while the Vojvodina province - Northern Serbia is one the least forest area in Europe with only 6\% under forest (Marković et al., 2017; Statistical Office of the Republic of Serbia, 2017). The diversity of natural conditions has resulted in the fact that the Vojvodina region is a typical agricultural region with pronounced urban areas. It is characterized by vast areas of arable land with crops. Besides the agriculture land, there are also areas under steppe, ponds, wetlands, and forests which are favorable habitats for diverse wildlife species as well (Marković et al., 2017).

Vojvodina Province was the pioneer and nowadays is still the leading region in Serbia in game and habitat management activity and protection (Ristić et al., 2009). Although game habitat is widely influenced by a range of biogeographical factors (Torres et al., 2011), recent researches have determined that available food (Virgós, Telléria, 1998) and land cover (Mysterud, Østbye, 1999; Borkowski, 2004; Borkowski, Ukalska 2008; Melis et al., 2009) are two essential factors. Furthermore, forest area is important in the form of the following components: as a food supplier, as a shelter provider, as the creator and regulator of the micro-climate of the habitat, etc. Whether it is a big or small game, vegetation plays an extremely important role in the survival of game in the hunting ground. Whether it is referred to as hunting or wildlife management, there is a conflict with the forest industry because of both wood production and wildlife management overlap in forests. Wildlife and forestry management practices had to evolve from the exploitation of natural resources to tools for sustainable management and at the same time to avoid losses in wood production, game, or biodiversity. 
All this indicates that forest management and determination of hunting capacity on which is being based is an important and responsible job on which hunting management is based. Given the importance of forest preservation an attempt was made to use Coordination of Information on the Environment (CORINE) Land Cover (CLC) in regional forest management in hunting grounds. Landscape elements are changing over time and the history of studying spatial changes through remote sensing begins with the launch of the first satellites for Earth observation in the second half of the 1960s. Methods and techniques for monitoring and analyzing spatial changes have evolved, and fast-growing interest in this topic is caused by the increasing attention and interests to the effects of global climate and anthropogenic changes (Théau, 2012). Spatial changes can most easily be observed by analyzing one of the land cover databases. Remote sensing and Geographic Information System (GIS) are the best methods to study spatial distribution related to land-cover and land-use changes (Popovici et al., 2013). Land cover changes are manifested as conversion which is presented as radical changes involving the replacement of one type of land cover by another, or modification which considers maintaining a certain type of intensive use without changing the terrain's attributes (Meyer, Turner, 1994; Gregorio, Jansen, 2000). For this research, we had in view to identify and analyze both category of changes in forest land cover. Nowadays, land cover change is generated principally by human activity for some individual or societal needs (Gavrilidis et al., 2015; Ianas, Germain, 2018). Landscape metrics can be used to compare the same landscapes within different periods. It is one of the most common analyses in geographical or landscape ecological researches (Klaučo et al., 2012). According to McGarigal and Marks (1994), Gustafson (1998), Forman (2006), and Gergel and Turner (2017) each land cover is possible to measure by landscape metrics for size, density, shape, edge, and diversity. The main aim of this paper is to analyze forestation changes as the number of patches (NP), class area (CA), and mean patch size (MPS) in period 2012-2018 in four different hunting ground types, using CLC which is an efficient tool for classification and estimation of land cover, and to improve hunting ground forest management in Vojvodina region as one of the least forested areas in Europe.

Corine Land Cover is in official use in the EU countries (Jovanović et al., 2018). It is a European program launched by the European Commission in 1985 based on the interpretation of satellite images to gather information related to the environment such as soil, water, land cover, biotopes, and so on (Neumann et al., 2007). Contrary to Normalized Difference Vegetation Indices (NDVI), a CLC has a broader scope and recognizes five groups: artificial surfaces, agricultural areas, forest and semi-natural areas, wetlands, and water bodies. It consists of an inventory of land cover in 44 classes. CORINE Land Cover is implemented in 5 to 10 year periods. This fits rather well with the observed CLC Change dynamics, which is below $1 \%$ change per year for almost all countries, except Portugal (Büttner et al., 2010). The main benefits of the change-mapping are direct interpretation and all changes larger than 5 ha can be easily delineated regardless of their geometric position. 
This research includes a combination of the use of publically available geographical data, geographical information systems, and landscape metrics in four different managing authorities of hunting grounds such as Public Company "Vojvodinasume", Serbian Armed Forces, National Park "Fruska gora" and Hunting organizations to analyze CLC changes in period 2012-2018. For purposes of this research, we have analyzed forest and semi-natural areas (land cover patches) where was detected broad-leaved forest, coniferous forest, mixed forest, natural grasslands, and transitional woodland-shrub.

\section{Materials and methods}

Study area - The Vojvodina region is situated in the northern part of Serbia and is a part of the Pannonia Basin. The study area includes 154 hunting grounds (Fig. 1) from which Hunting organizations are managing with 134 hunting grounds (all hunting ground are open), PC "Vojvodinasume" with 17 (14 hunting grounds are fenced and 3 are semi fenced), Serbian Armed Forces with two (one open and one fenced) and National Park "Fruska gora" with one hunting ground (open hunting ground). Hunting organizations in Vojvodina own the largest agriculture land since Vojvodina is a lowland region with the highest agriculture surface in Serbia with low forest coverage. All hunting grounds in Vojvodina encompass 2,158,012 ha. Vojvodina stands out as a region in Serbia with the highest number of hunting grounds, since it covers around one-quarter of the territory of Serbia and it gathers around one-half of all hunting grounds in the country. This is due to the fragmentation of hunting grounds which occurred recently in Vojvodina to establish new hunting regions (Lavadinović, 2016).

Figure 1. Hunting grounds in Vojvodina province

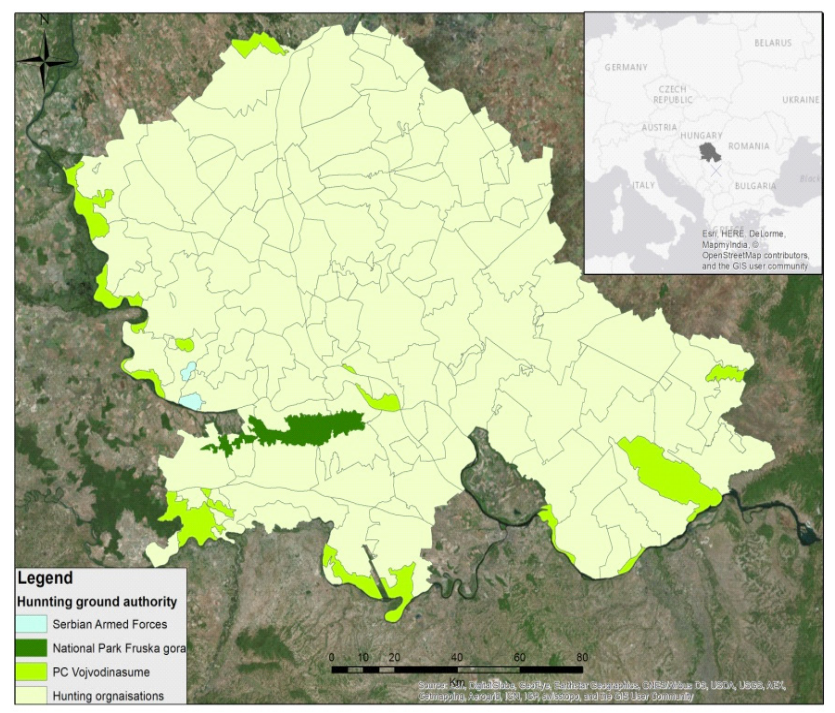

Source: authors 
The major part of forests and forestland in the Vojvodina region are located in fenced hunting grounds where forest activities are the most intensive. National forest inventory in Serbia has been performed very rarely (approximately every 20 years) in the past. Since 2007 official estimates of the forest inventory have been made every year. The data for this research were downloaded from the Copernicus platform (https://land.copernicus. $\mathrm{eu} /$ ) in the form of a Corine Land Cover (CLC) database. CLC inventory was initiated in 1985. Updates have been produced in 2000, 2006, 2012, and 2018 so it is even possible to compare with official estimates of the forest inventory. CLC uses a Minimum Mapping Unit (MMU) of 25 hectares (ha) for areal phenomena and a minimum width of $100 \mathrm{~m}$ for linear phenomena. The time series are complemented by change layers, which highlight changes in land cover with an MMU of 5 ha (EEA, 2007). CLC dates are obtained using satellite image processing, GIS integration, and generalization. For the CLC Change dynamics, satellite data were obtained from IRS P6 LISS III and Rapid Eye dual date for the year 2012, and Sentinel-2 and Landsat-8 for gap filling for the year 2018 with thematic accuracy $\geq 85 \%$. GIS is becoming a powerful tool not only in geographic sciences but also in environment data processing such as game habitat conditions. For this research, all analysis has been facilitated by the ArcGIS 9.e software by ESRI to produce thematic maps for a more visual description of parameters' size, distribution, and correlation. Maps were made in WGS_1984_UTM_Zone_34N Projected Coordinate System, D_WGS_1984 Datum, with Prime Meridian Greenwich. The obtained information allowed us to assess changes in space-and-time and to identify the types of change during the observed period.

\section{Results and discussion}

After data processing, it was determined that all hunting grounds in Vojvodina encompass $2,158,012$ ha what is almost the whole territory of Vojvodina province - 2,161,551 ha (Statistical Office of the Republic of Serbia, 2017). The forest area encompassed 135,871 ha in 2012 (6.29\% of the total territory) and 134,697 ha in 2018 (6.23\% of the total territory) (Table 1). When these CLC results are compared with official estimations of the National forest inventory or PC "Vojvodinasume" there is a small difference. For instance, according to the National forest inventory (Statistical Office of the Republic of Serbia, 2017) the forest area was smaller and encompassed 123,811 ha in 2014 (5.72\% of the total territory), and 131,452 in 2017 (6.08\% of the total territory). On the other hand, according to estimates of the PC "Vojvodinasume" total forest area was higher than CLC and was 140,717 (6.51\%).

Table 1. Forest and shrub detection changes in Vojvodina

\begin{tabular}{|l|r|r|r|r|}
\hline \multirow{2}{*}{ Land cover/Landscape metric } & \multicolumn{2}{|c|}{$\mathbf{2 0 1 2}$} & \multicolumn{2}{c|}{$\mathbf{2 0 1 8}$} \\
\cline { 2 - 5 } & \multicolumn{1}{c|}{ ha } & \multicolumn{1}{c|}{ NP } & \multicolumn{1}{c|}{ ha } & \multicolumn{1}{c|}{ NP } \\
\hline Broad leaved forest - 311 & 128479 & 442 & 127306 & 436 \\
\hline Coniferous forest-312 & 2344 & 31 & 2234 & 29 \\
\hline Mixed forest-313 & 5048 & 66 & 5157 & 69 \\
\hline Natural grasslands-321 & 40372 & 99 & 39718 & 101 \\
\hline Transitional woodland-shrub-324 & 57578 & 621 & 58792 & 634 \\
\hline
\end{tabular}

Source: authors' calculations/Legend: NP- Number of patches 
In the observed period, broad-leaved forests and shrub and herbaceous vegetation associations registered major changes. Looking at the change detection (Figure 2) the most frequent land cover flows were deforestation and afforestation.

Figure 2. Forest changes 2012-2018 in hunting grounds

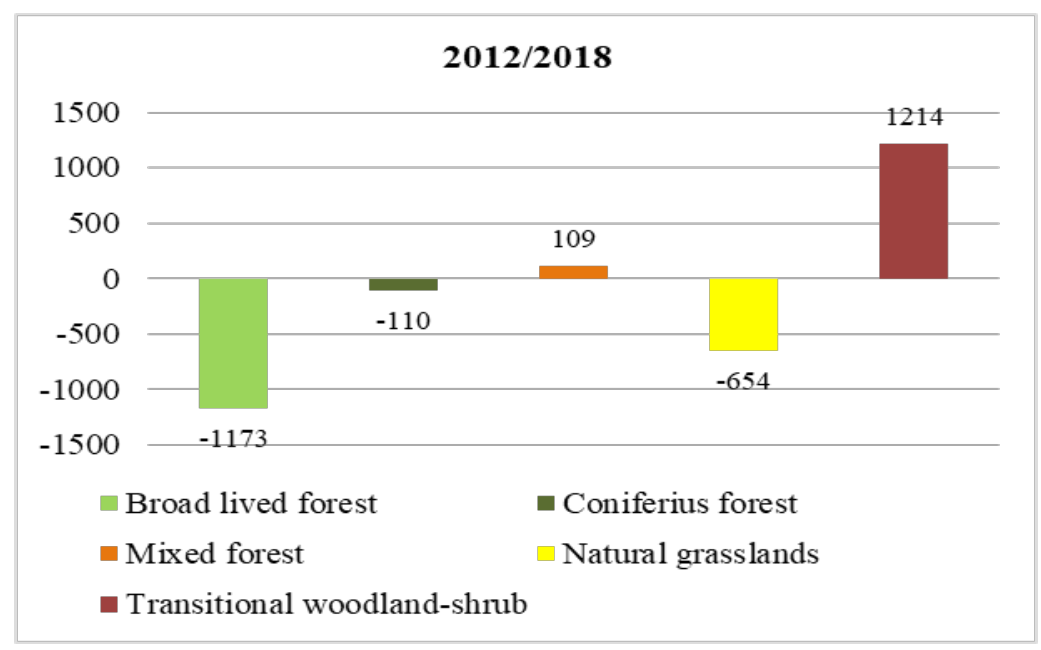

Source: authors' calculations

We used CLC change 2012-2018 seamless vector data to the created map. For this research purpose, we divided all changes into three groups: replacement from all other CLC classes to forests, shrubs, and herbaceous vegetation; modification among forests, shrubs, and herbaceous vegetation classes and replacement from forests, shrubs, and herbaceous vegetation to any other CLC class (Figure 3).

Figure 3. CLC changes map 2012-2018

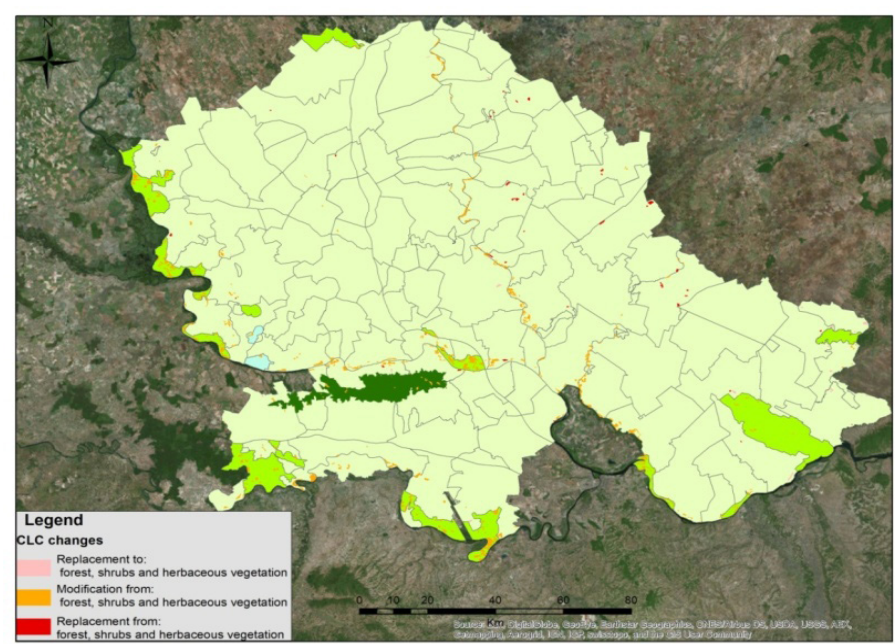

Source: authors 
After, when the CLC change was applied into four different hunting grounds types following results became apparent as shown (Table 2 - 5).

Table 2. CLC changes in PC "Vojvodinasume"

\begin{tabular}{|l|r|r|r|r|r|r|}
\hline Land cover/Landscape metric & \multicolumn{2}{|c|}{ NP } & \multicolumn{2}{|c|}{ CA (ha) } & \multicolumn{2}{|c|}{ MPS (ha) } \\
\hline Broad leaved forest - 311 & - & 78 & - & 1640 & + & 4.71 \\
\hline Coniferous forest - 312 & - & 4 & - & 117 & - & 13.66 \\
\hline Mixed forest - 313 & + & 3 & + & 109 & + & 1.65 \\
\hline $\begin{array}{l}\text { Transitional woodland- } \\
\text { shrub-324 }\end{array}$ & + & 82 & + & 1692 & - & 5.03 \\
\hline
\end{tabular}

Source: authors' calculations

Legend: NP-Number of patches; CA-Class area; MPS-Mean patch size

Table 3. CLC changes in Hunting organization

\begin{tabular}{|l|r|r|r|r|r|r|}
\hline \multicolumn{1}{|c|}{ Land cover/Landscape metric } & \multicolumn{2}{|c|}{ NP } & \multicolumn{2}{c|}{ CA (ha) } & \multicolumn{2}{c|}{ MPS (ha) } \\
\hline Broad leaved forest - 311 & - & 51 & + & 254 & + & 9.91 \\
\hline Natural grasslands - 321 & - & 27 & - & 443 & - & 16.40 \\
\hline $\begin{array}{l}\text { Transitional woodland-shrub - } \\
324\end{array}$ & + & 56 & + & 45 & - & 7.85 \\
\hline
\end{tabular}

Source: authors' calculations

Table 4. CLC changes in Serbian Armed Forces

\begin{tabular}{|l|r|r|r|r|r|r|}
\hline Land cover/Landscape metric & \multicolumn{2}{|c|}{ NP } & \multicolumn{2}{c|}{ CA (ha) } & \multicolumn{2}{c|}{ MPS (ha) } \\
\hline Broad leaved forest - 311 & - & 3 & - & 98 & - & 32.66 \\
\hline $\begin{array}{l}\text { Transitional woodland-shrub - } \\
324\end{array}$ & + & 3 & + & 98 & + & 32.66 \\
\hline
\end{tabular}

Source: authors' calculations

Table 5. CLC changes in National Park Fruska gora

\begin{tabular}{|l|r|r|r|r|r|r|}
\hline \multicolumn{1}{|c|}{ Land cover/Landscape metric } & \multicolumn{2}{|c|}{ NP } & \multicolumn{2}{c|}{ CA (ha) } & \multicolumn{2}{c|}{ MPS (ha) } \\
\hline Broad leaved forest - 311 & - & 4 & + & 146 & + & 28.49 \\
\hline Transitional woodland-shrub -324 & + & 4 & - & 146 & - & 28.49 \\
\hline
\end{tabular}

Source: authors' calculations

Legend: NP- Number of patches; CA-Class area; MPS-Mean patch size

Results obtained through the application of CLC reveal different levels of land cover changes in investigated hunting grounds. The broad-leaved forest areas obtained using CLC changes 2012-2018 (Class 311) shrank by 1640 ha in hunting grounds managed by PC "Vojvodinasume" and Serbian Armed Forces (for 98 ha). On the other hand, the broad-leaved forest areas have increased in hunting grounds managed by National Park "Fruska gora" (for 146 ha) and hunting organizations (for 254 ha). Changes in coniferous (Class 312) and mixed forests (Class 313) were recorded only in hunting grounds managed by PC "Vojvodinasume" where the area under coniferous forests declined for 117 ha and increased for 109 ha in the case of mixed forests. Natural 
grasslands area (Class 321) shrank by 443 ha and has been recorded only in hunting ground by hunting organizations. Regarding transitional woodland-shrub (Class 324), there is a growth in hunting grounds managed by PC "Vojvodinasume" (for 1692 ha), Serbian Armed Forces (for $98 \mathrm{ha}$ ), and Hunting organizations (for $45 \mathrm{ha}$ ) while in hunting ground managed by National Park Fruska gora area declined for 146 ha.

The number of patches (NP) changes has the same trend in every class in every hunting area where have been recorded. There were less broad-leaved forest, coniferous forest, and natural grasslands NP, while in mixed forest and transitional woodland-shrub the NP has an increase in the observed period. From the number of patches and their area, it is possible to determine the mean patch size (MPS). Output values from MPS changes indicate that following land cover patches vary in size regardless of class type but not to hunting ground authority. The relatively small difference in MPS changes between the classes among the different hunting ground types, compared to the higher difference in their surface, indicate that the hunting grounds by hunting organizations are the most fragmented, contrary to other types. As the forested area began shrinking, the quality of land as game habitat started deteriorating significantly.

Habitat evaluation is a complex indicator of vital conditions for certain species of game. It requires a realistic assessment of habitat conditions in the hunting ground, knowledge of the ecology of the game, and professional planning. Assessment of habitat conditions in the hunting ground also relates to the presence of natural food sources (pastures, fruiting shrubs, and trees, etc.) and natural shelters (for rest, protection of youngling). Regarding the game species management, land cover changes should strive to land cover fragmentation instead of land cover unification. In this case, there are three different scenarios. The most desirable is if NP and CA increase and MPS decrease. An unfavorable scenario is if NP and CA decrease and MPS increase. All other combination of NP, CA, and MPS changes it doesn't influence on fragmentation or merging to great extent. Regarding the abovementioned importance of fragmentation in terms of forest land cover types, it could be concluded that the optimal scenario is presented in transitional woodland-shrub (Class 324) in hunting grounds managed by PC "Vojvodinasume" where NP is greater for 82 patches, CA for 1692 ha and MPS is lesser for 5.03 ha. The same situation but to a smaller extent is the same class (Class 324) in hunting ground managed by hunting organization where NP is greater for 56 patches, CA for 45 ha and MPS is lesser for 7.85 ha. On the other hand, the most unfavorable case is also in hunting grounds managed by PC "Vojvodinasume", in the broad-leaved forest (Class 311) where NP is lesser for 78 patches, CA for 1640 ha and MPS is higher for 4.71 ha.

\section{Conclusions}

Despite certain shortcomings that are reflected in rarely update (every five to ten years) and the fact that CLC is a predominantly regional database and to a certain extent is imprecise (CLC doesn't go under 5 ha) it surpasses old forest inventory techniques. Through our analysis, it became evident that CLC change in GIS could be an efficient tool in forest management overview in the Vojvodina region. GIS-based assessment 
of land-cover changes over the observed period, according to the CLC database, highlighted a wide range of modifications in the land-cover pattern, basically transition from one category of use to another.

The results show that in the National Park and Serbian Armed Forces hunting grounds the broad-leaved forest areas occurred on the surfaces that were under the transitional woodland-shrub and vice versa. A similar situation is in the hunting grounds managed by PC "Vojvodinasume" where there is not only the most intensive logging of broadleaved and coniferous forests but also the most intensive afforestation of mixed forests and transitional woodland-shrub. In the above mention, three types of hunting grounds the ratio logging-planting is almost equal. This indicates artificial reforestation i.e. planting after logging or establishment of new forest on degraded lands. Usually, for Public Companies like "Vojvodinasume" or National Park, as well as for the Military, the greatest threats result from activities of using natural resources such as forestry practices and activities. On the other hand, in the hunting grounds managed by hunting organizations, there is the highest area growth under the broad-leaved forest. The increase in forests can be explained by increased awareness of their importance for wildlife.

As a result of initiatives by the Provincial Government and local authorities, the changes in the study area have been characterized by the very low growth of forest landscapes or even shrinkage in some pilot areas, which's aimed to increase the forestation level of the area and to revitalize degraded sites.

CLC changes are very useful in countries like Serbia that rarely conduct national forest inventories, especially when the investigated area is one of the least forested areas in Europe. This methodology is very cheap and quick, easy to implement, and gives to government, ministries, forest managers in hunting grounds, and all other stakeholders very useful information which can help in the development of forest policies and possible issues in forest management. Incentives to good forestry practice must find their place in the forestry and agricultural policy measures.

\section{References}

1. Borkowski, J. (2004) Distribution and habitat use by red and roe deer following a large forest fire in Southwestern Poland. Forest ecology and management, 201 (23): 287-293 https://doi.org/10.1016/j.foreco.2004.07.011

2. Borkowski, J., Ukalska, J. (2008) Winter habitat use by red and roe deer in pinedominated forest. Forest ecology and management, 255 (3-4): 468-475. https://doi. org/10.1016/j.foreco.2007.09.013

3. Brack, D. (2003) Illegal logging and the illegal trade in forest and timber products. International Forestry Review 5(3): 195-198. https://doi.org/10.1505/ IFOR.5.3.195.19148

4. Büttner, G., Kosztra, B., Maucha, G., Pataki, R. (2010) Implementation and Achievements of CLC2006, Final Draft. ETC-LUSI, Barcelona, 65 p. 
5. Chowdhury, R.R. (2006) Driving forces of tropical deforestation: The role of remote sensing and spatial models. Singapore Journal of Tropical Geography 27(1): 82101. https://doi.org/10.1111/j.1467-9493.2006.00241.x

6. Dale, V.H. (2008) Managing Forests as Ecosystems: A success story or a challenge ahead? In: Pace M.L., Graffman P.M. (ed.), Success, Limitations and Frontier in Ecosystem Sceince, Springer-Verlag, New York, 50-68.

7. EEA-European Environmental Agency (2007) CLC 2006 techical guidelines. EEA, Copenhagen, $70 \mathrm{p}$.

8. Forman, R. T. T. (2006) Land Mosaics: The Ecology of Landscapes and Regions. Cambridge University Press, Cambridge, 632 p.

9. Gavrilidis, A. A., Grădinaru, S. R., Iojă, I. C., Cârstea, E. M., Pătru-Stupariu, I. (2015) Land Use and Land Cover Dynamics in the periurban area of an industrialized est-european city: an overview of the last 100 years. Carpathian Journal of Earth and Environmental Sciences 10(4): 29-38.

10. Gergel, S. E., Turner, M. G. (2017) Learning landscape ecology: a practical guide to concepts and techniques - Second edition. Springer, New York, $350 \mathrm{p}$.

11. Gregorio, A., Jansen, L. (2000) Land Cover Classification System. Classification concepts and user manual. FAO, Rome, 179, p.

12. Gustafson, E. J. (1998) Quantifying landscape spatial pattern: What is the state of the art? Ecosystems 1(2): 143-156. https://doi.org/10.1007/s100219900011

13. Ianas, A., Germain, D. (2018) Quantifying landscape changes and frangmentation in a National Park in the Romanina Carpathians. Carpathian Journal of Earth and Environmental Sciences 13(1): 147-160.

14. Jovanović, M., Milanović, M. (2015) Normalized Difference Vegetation Index (NDVI) as the Basis for Local Forest Management. Example of the Municipality of Topola, Serbia. Polish Journal of Environmental Studies 24(2): 529-535.

15. Jovanović, M., Milanović, M., Zorn, M. (2018) The use of NDVI and CORINE Land Cover databses for forest management in Serbia. Acta geographica Slovenica 58(1): 110-123. https://doi.org/10.3986/AGS.818

16. Klaučo, M., Weis, K., Stankov, U., Arsenović, D., Marković, V. (2012) Ecological Significance of Land-Cover Based on Interpretation of Human-Tourism Impact. A Case from Two Different Protected Areas (Slovakia and Serbia). Carpathian Journal of Earth and Environmental Sciences 7(3): 231-246.

17. Lavadinović, V. (2016) Analysis of the hunting sector in Republic of Serbia. Faculty of Environment and Natural Resources, Freiburg im Breisgau, 191 p.

18. Marković, V., Vasiljević, Dj., Jovanović, T., Lukić, T., Vujičić, M., Kovačević, M., Ristić, Z., Marković, S., Ristanović, B., Sakulski, D. (2017) The effect of natural and human-induced habitat conditions on number of roe deer: case stuty of Vojvodina, Serbia. Acta geographica Slovenica 57(2): 58-69. https://doi.org/10.3986/AGS.903

19. Markus-Johannson, M., Mesquita, B., Nemeth, A., Dimovski, M., Monnier C., Kiss-Parciu, P. (2010) Illegal logging in South Eastern Europe. REC, Szentendre, $136, \mathrm{p}$. 
20. McGarigal, K., Marks, B. (1994) FRAGSTATS. Spatial pattern analysis program for quantifying landscape structure. Pacific Northwest Research Station, Portland, $122 \mathrm{p}$.

21. Melis, C., Jedrzejewska, B., Apollonio, M., Barton, K., Jedrzejewski, W., Linnell, J., Kojola, I., Kusak, J., Adamic,M.,Ciuti, S., Delehan, I., Dykyy, I., Krapinec, K., Mattioli, K., Sagaydak, A., Samchuk, N., Schmidt, K.,Shkvyrya, M., Sidorovich, V., Zawadzka, B., Zhyla, S. (2009) Predation has a greater impact in less productive environments: variation in roe deer, Capreolus capreolus, population density across Europe. Global ecology and biogeography 18 (6): 724-734. https://doi.org/10.3986/ AGS.903

22. Meyer, W.B., Turner, B.L. (1994) Changes in Land Use and Land Cover: A Global Perspective. Cambridge University Press, Cambridge, 537 p.

23. Monteiro, A., Souza, C. (2012) Remote Monitoring for Forest Management in the Brazilian Amazon. In: Diez, J., J. (ed.), Sustainable Forest Management-Current research, InTech, Rijeka, 67-86.

24. Mysterud, A., Ostbye, E. (1999) Cover as a habitat element for temperate ungulates: effects on habitat selection and demography. Wildlife society bulletin 27(2): 385-294.

25. Neumann, K., Herold, M., Hartley, A., Schmullius, C. (2007) Comparative assessment of CORINE2000 and GLC2000: Spatial analysis of land cover data for Europe. International Journal of Applied Earth Observation and Geoinformation 9 (4): 425-437. https://doi.org/10.1016/j.jag.2007.02.004

26. Počuča, M., Matijašević Obradović, J., Drašković, B. (2017). Correlation between the air quality index SAQI_11 and sustainable rural development in the Republic of Serbia. Economics of Agriculture, 64(3), 1249-1262. doi:10.5937/ekoPolj1703249P.

27. Popovici, E. A., Bălteanu, D. \& Kucsicsa, G. (2013) Assessment of changes in Land-Use and LandCover Pattern in Romania using Corine Land Cover Database. Carpathian Journal of Earth and Environmental Sciences 8(4): 195-208.

28. Radivojević, V., Krstić, B., Krstić, M., Petković, M. (2019). Benchmarking agricultural and other environmental performances of Central and East european countires. Economics of Agriculture, 66(2), 471-484. DOI: doi:10.5937/ ekoPolj1902471R

29. Ristić, Z. A., Marković, V., Dević, M. (2009) Development of hunting tourism in Vojvodina. Geographica Pannonica 13(3): 105-114. doi:10.5937/GeoPan0903105R

30. Statistical Office of the Republic of Serbia, 2017. Bulletin of Forestry in Republic of Serbia. Statistical Office, Belgrade, 80 p. (In Serbian).

31. Steininger, M.K., Tucker, C. J., Townshend, J.R.G., Killeen, T. J., Desch, A., Bell, V., Ersts, P. (2001) Tropical deforestation in the Bolivian Amazon. Environment Conservation Journal28(2): 127-134. https://doi.org/10.1017/S0376892901000133

32. Tomaš Simin, M., Rodić, V., Glavaš Trbić, D. (2019). Organic agriculture as an indicator of sustainable agricultural development: Serbia in focus. Economics of Agriculture, 66(1), 265-280. DOI: doi:10.5937/ekoPolj1901265T 
33. Torres, R. T., Santosa, J., Linnell, J. D. C., Virgós, E., Fonseca, C. (2011) Factors affecting roe deer occurrence in a Mediterranean landscape, Northeastern Portugal. Mammalian biology 76(4): 491-497. https://doi.org/10.1016/j.mambio.2010.10.013

34. Théau, J. (2012) Change detection. In: Kresse, W., Danko, D. (ed.), Springer Handbook of Geographic Information, Springer Handbooks, Berlin, 175-184.

35. Tracy, L. A., 1994. The deforestation of Siberia: economic and environmental problems in Russian Forest Management. Forest Industry Lecture, Edmonton, 10 p.

36. Virgós, E., Telléria, J. L. (1998) Roe deer habitat selection in Spain: constraints on the distribution of a species. Canadian journal of zoology 76 (7): 1294-1299. https://doi.org/10.1139/z98-065

37. Vukajlović, Đ., van Veghel, H., Đurović, S. (2017). Economic justification for floriculture development in Serbia. Economics of Agriculture, 64(2), 687-699. doi:10.5937/ekoPolj1702687V

38. https://land.copernicus.eu/pan-european/corine-land-cover/\# 